\title{
44.4. LATE TERTIARY CHANNEL SYSTEM IN NORTHERN LIBYA AND ITS IMPLICATIONS ON MEDITERRANEAN SEA LEVEL CHANGES
}

\author{
F. T. Barr and B. R. Walker, Oasis Oil Company of Libya, Inc., Tripoli, Libya
}

\begin{abstract}
A large fossil drainage system of probable upper Miocene age is recognized along the northeastern flank of the Sirte Basin, northern Libya. The main channel has been traced for about 150 $\mathrm{km}$ eventually being lost under the sarir, just south of Qasr as Sahabi. It has cut into middle Miocene limestone to a depth of over 1300 feet. In this region the surface is near present sea level.

It is postulated that the Sahabi drainage system is the result of an abrupt drop in Mediterranean sea level of at least 1300 feet, and probably more than 2000 feet, during the late Miocene. During the early Pliocene, the sea returned to a level about the same as, or a little less than, that just prior to the late Miocene regression.

Other possible late Miocene drainage systems have been recorded in eastern Libya and the western Desert of Egypt; these may be related to the same sequence of late Tertiary events that affected a great portion of the eastern Mediterranean region.

These Neogene geomorphic features of northeastern Africa, which have long been a perplexing problem, now fit well into an hypothesis which accommodates much of the new data obtained from drilling beneath the floor of the Mediterranean Sea.
\end{abstract}

\section{INTRODUCTION}

Geophysical crews prospecting for oil along the eastern margin of the Sirte Basin, northern Libya, during the late 1960 's, experienced severe velocity problems in the upper 1000 to 2000 feet of surface sediments. Seismic velocities often changed abruptly in this shallow sequence indicating rapid lithologic changes. These sharp velocity changes sometimes coincided with a dry drainage system that occasionally could be observed on the desert surface. It was then recognized that this ancient drainage system, which was of considerable magnitude, was affecting seismic surveys in this area much more than would normally be expected.

A program was initiated to drill a number of shallow holes in this area down to maximum depths of about 920 feet to solve local "weathering" problems, including the definition of the channel system. Stratigraphic and geophysical information derived from this program aided in recognizing the main erosional channels in several areas. However, the heterogeneity of strata and magnitude of the drainage system required a method of closer and deeper control for adequate definition of the principal channels. This was supplied by a refraction crew whose activities were coordinated with those of the shallow hole program.

Information from this program, supplemented with data from field and wildcat wells, has shown the presence of a major late Tertiary fossil drainage system extending for tens of miles that would appear to have significant implications regarding the Neogene history of central Libya and eastern Mediterranean.

\section{DESCRIPTION OF CHANNEL SYSTEM}

This channel system is recognized along the northeastern flank of the Sirte Basin between latitude $29^{\circ}$ to $30^{\circ}$ North, and longitude $20^{\circ} 45^{\prime}$ to $22^{\circ}$ East. Within this area, the closeness of the control used to define this system varies considerably. In a few cases, closely spaced series of holes have been drilled across the main channel. In others, and especially to the south, control data become sparse and sometimes for many miles the channel is only defined by a single hole together with the surface expression of the drainage system.

Our knowledge of the total extent of this fossil drainage system is obviously fragmentary. The available data indicate, however, that the main channel runs in a northwest direction for over $100 \mathrm{~km}$, then in a westerly or southwesterly direction for over $50 \mathrm{~km}$, and eventually it becomes lost under the sarir about $20 \mathrm{~km}$ south of Qasr as Sahabi. The main drainage course is referred to as the Sahabi channel. A large tributary joins the main channel about $50 \mathrm{~km}$ southeast of Qasr as Sahabi after having run due west for at least $45 \mathrm{~km}$. Because of the magnitude of the recognized portions of this system, it is suspected by the authors that this drainage may extend a much greater distance to the south.

On the accompanying sketch map (Figure 1), the channels are illustrated as being rather straight. In areas of closest control there is a suggestion that they may have a slightly more sinuous nature, probably being influenced by the gentle topography encountered on the middle Miocene limestone surface. However, the drainage system appears youthful with no indications of meandering. 


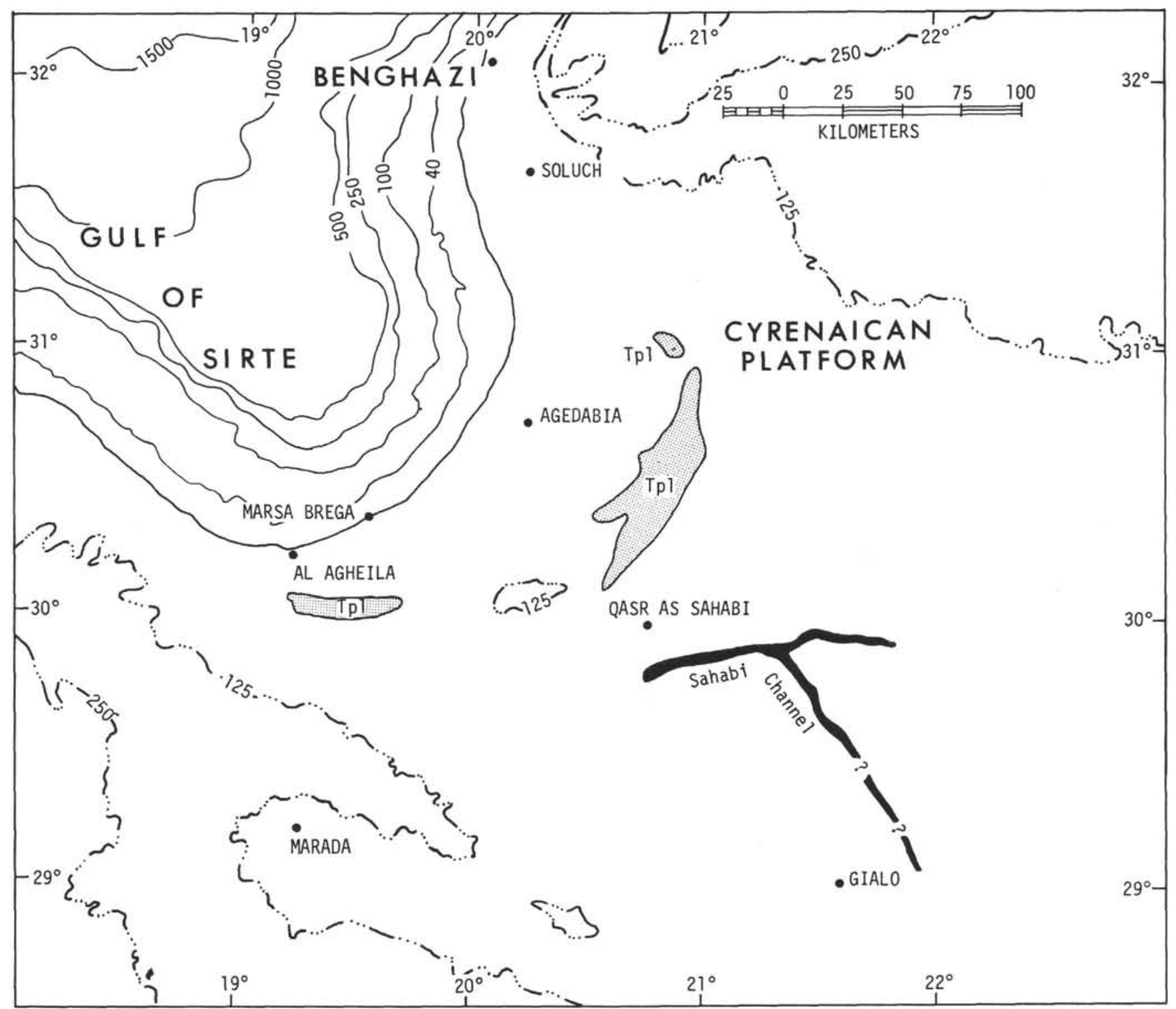

Figure 1. Map of north-central Libya showing location of Sahabi channel system and distribution of Pliocene (Tpl) outcrops. Topographic contours are in feet; bathymetric contours are in meters.

The main channel is steep-sided with a maximum depth greater than the 920 feet of the deepest holes drilled. None of the deep wildcat wells in this area were located over the deepest part of the main channel. However, a maximum depth for the channel in excess of 1300 feet was calculated from the seismic shallow refraction surveys (Figure 2). This depth is judged to be fairly accurate because when nearby holes penetrated the shallower subsidiary channel the drill depths and geophysically calculated depths agreed closely. The breadth of the Sahabi channel appears to vary from less than a kilometer to a maximum of over $5 \mathrm{~km}$.

In addition to the fairly well delineated Sahabi channel, fragmentary seismic data indicate a similar filled channel to the northwest, nearer the apex of the Gulf of Sirte. This channel appears to have a maximum depth of 1800 to 2000 feet. Although it is not completely documented, we believe it is the northwestern extension of the Sahabi channel.
The Sahabi channel system has been cut into a sequence of middle Miocene carbonate rocks which is exposed at the surface over much of this area. These rocks usually consist of well-lithified, highly fossiliferous calcarenite and dolomite. Thin interbeds of dark shale and rare gypsum are also present. A diverse foraminiferal fauna which includes numerous specimens of Borelis melo (Fichtel and Moll) is usually present. This species is characteristic of much of the widespread middle Miocene carbonate rocks of Cyrenaica. This sequence is assignable to the $\mathrm{Al}$ Jaghbub Formation (Bellini, 1969) and is also similar lithologically and paleontologically to the middle Miocene Regima Formation of northern Cyrenaica (Kleinsmeide and van den Berg, 1968) and the Marmarica Limestone of the western Desert of Egypt (Said, 1962a, 1962b).

The sediments that fill the channels are quite distinct from the middle Miocene host rock. These sediments 

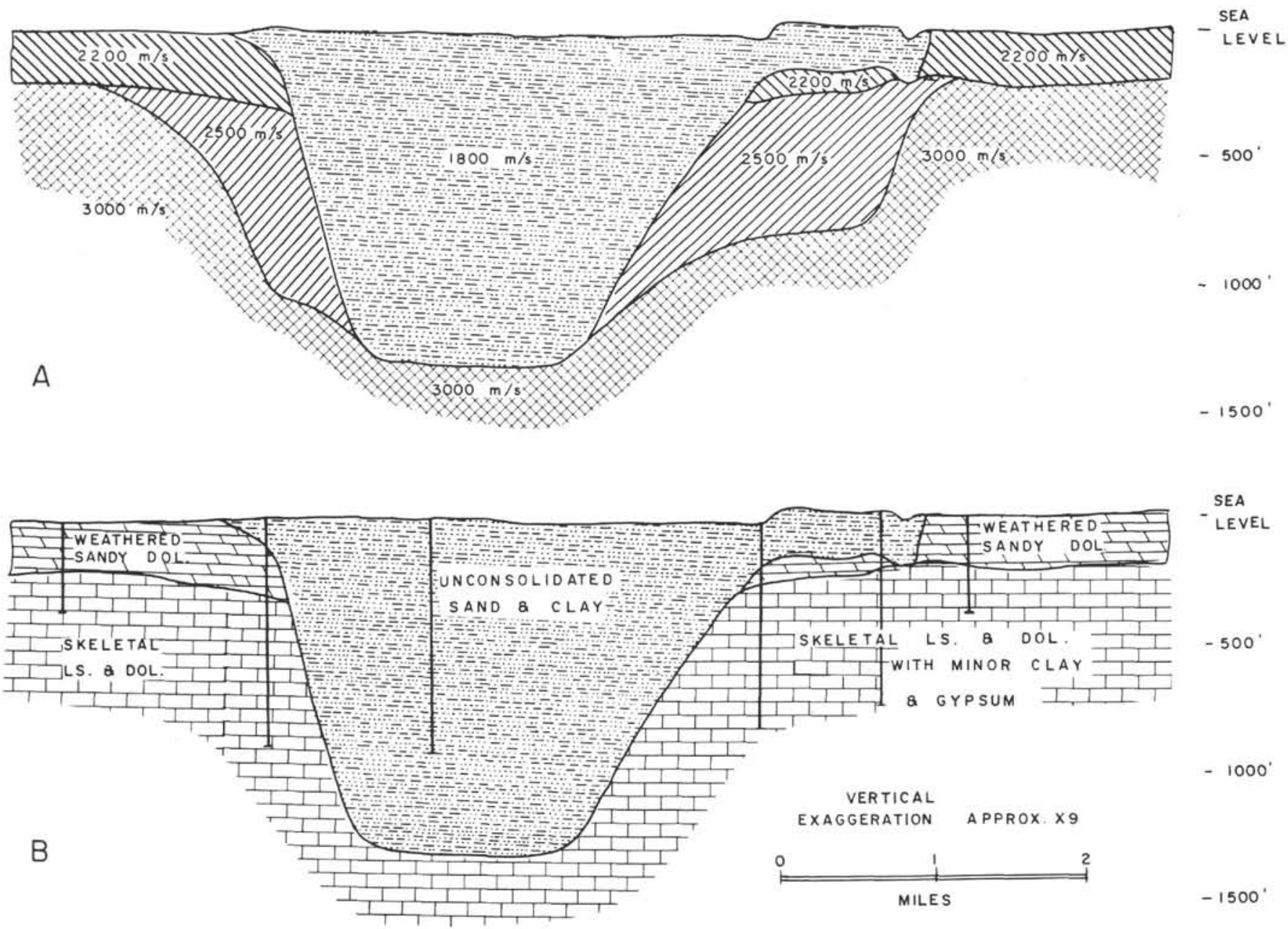

Figure 2. Slightly oblique cross sections across the main channel southeast of Qasr as Sahabi. (A) Refraction profile across channel showing velocities in meters per second of channel fill $(1800 \mathrm{~m} / \mathrm{s})$, weathered zone $(2200 \mathrm{~m} / \mathrm{s})$, partially leached bed rock $(2500 \mathrm{~m} / \mathrm{s})$ and unaltered bed rock $(3000 \mathrm{~m} / \mathrm{s})$. (B) Lithologic profile across the same traverse based on a series of shallow bore holes supplemented by seismic data.

consist of unconsolidated quartz sand, silt, and clay. The sands and clays are equiproportional, although samples may vary from entirely sand to completely clay. The sands usually are uncemented although they are accompanied by some clay matrix. Also, they vary widely from very coarse to fine grained, and from rounded to angular. Some of the more spherical quartz grains have been frosted. Sorting may also vary considerably, although moderate to well-sorted sands in the fine to medium range predominate. Mica and carbonate grains, although usually rare, are locally common. Rare grains of feldspar, glauconite (derived), and dark minerals are recorded. The clays are soft, non-calcareous, and occasionally pyritic.

The channel fill sediments are usually unfossiliferous except for an occasional ostracod or mollusc fragment. A few foraminifera have been recovered, but they are extremely worn and, along with the rare glauconite grains, are considered derived from the middle Miocene host rock.

The nature of these sediments suggests that they were deposited under non-marine, fluvial conditions. A possible source might be the continental Tertiary beds at a considerable distance to the southeast. There also appears to be some windblown material incorporated in this deposit.

\section{LATE TERTIARY HISTORY OF NORTHEASTERN AFRICA}

In order to evaluate the possible events that may have been responsible for the Sahabi channel system, the late Tertiary history of northeastern Africa is briefly reviewed.

\section{Miocene (pre-Messinian)}

Marine deposits of middle Miocene age are widespread across much of the northern portions of Tunisia, Libya, and Egypt (Figure 3). In general, this was a time of renewed transgression along the southeastern coast of the Mediterranean. After the initial transgression, stable conditions prevailed over much of northern Cyrenaica and the western desert of Egypt and resulted in the deposition of rather uniform shallow marine carbonates over a broad area.

In Tunisia, local orogeny was important and resulted in the formation of a number of small basins with somewhat different histories. At the end of the Oligocene, most, if not 


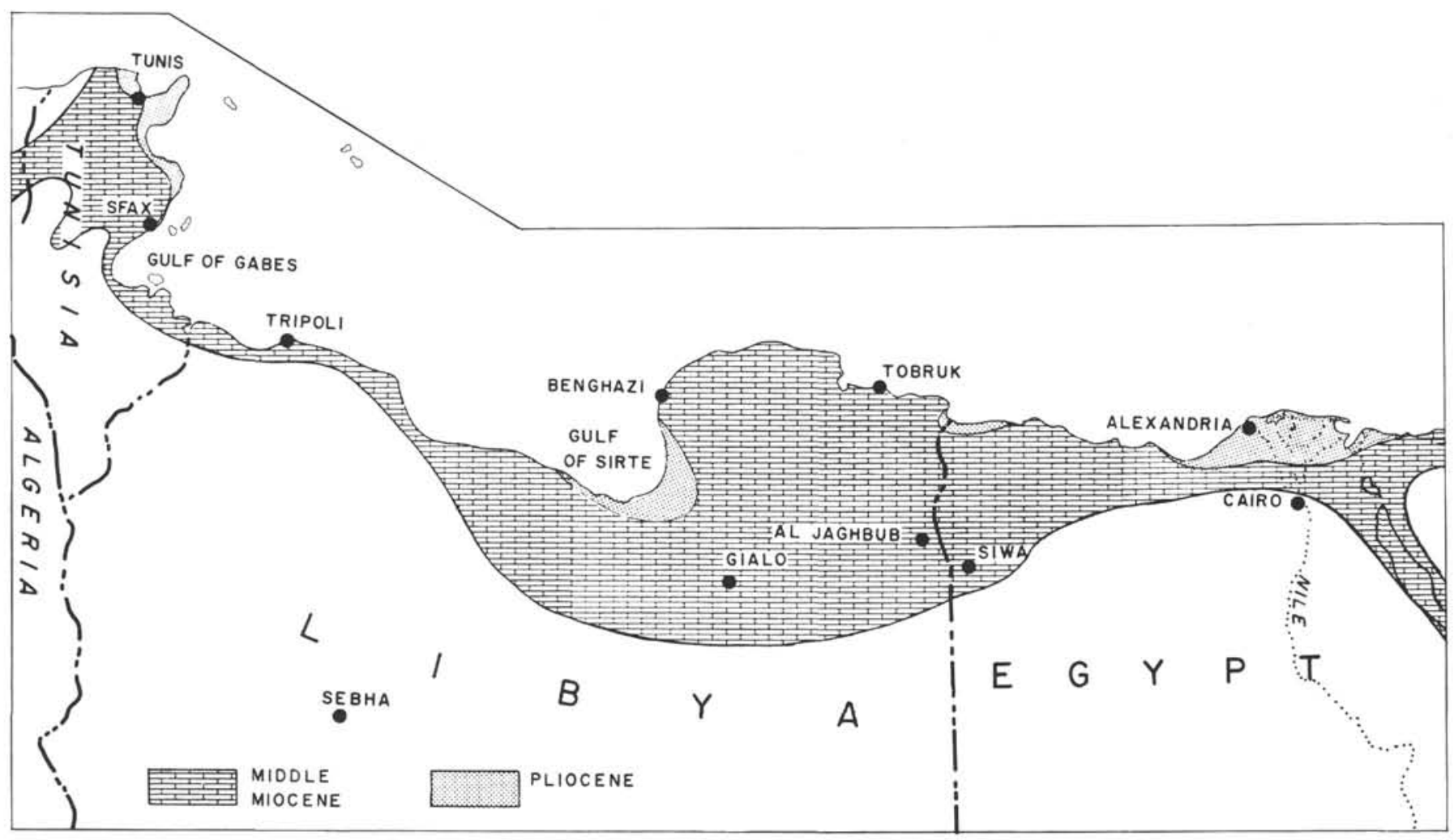

Figure 3. Paleogeographic sketch map showing distribution of the Middle Miocene and Pliocene seas in northeastern Africa.

all, of Tunisia was briefly emergent. Then during the early Miocene, a marine transgression from the east or northeast commenced and continued into the Vindobonian. By mid-Miocene time, much of northeastern and central Tunisia was inundated by marine seas. Southern and northwestern-most Tunisia remained emergent. These Vindobonian sediments consist mainly of shallow marine gray shales and marls with some thin sandstone, limestone, and occasional lignite beds. This sequence is called the Oum Douil Formation (Burollet, 1967) and attains a maximum thickness in excess of 1000 feet.

In Libya, the Miocene was also a time of transgression following a brief emergence at the end of the Oligocene, at least in the coastal areas of Cyrenaica and Tripolitania. Sedimentation across the Oligocene-Miocene boundary in the deeper parts of the Sirte Basin may have been uninterrupted. However, there is an unconformable relationship along the margins of the basin. Middle Miocene sediments are present in Tripolitania only along the coastal area; on the Jefara. In the Sirte Basin, which consists of differentially subsiding horsts and grabens, the Miocene sequence varies greatly in lithofacies and thickness. In the deeper and more rapidly subsiding troughs, thick sequences of dark shales containing an abundant planktonic foraminiferal assemblage (Berggren, 1969) are present. On the shoaler horst blocks, shallow carbonates, including coralline deposits, usually prevail. In northeastern Libya, uniform deposits of shallow marine chalky calcarenites, containing the diagnostic foraminifer Borelis melo, cover much of the Cyrenaica platform. These limestones, which are assigned to the Al Jaghbub and Regima Formations in
Libya, extend across into the western desert of Egypt as the Marmarica Limestone. Bellini (1969) records a thickness of 115 meters for the Al Jaghbub Formation in its type area and Said $(1962$ b, p. 203, 204) reports similar thicknesses for the Marmarica Limestone in the western desert.

In the Cairo-Suez area of Egypt, Miocene rocks again represent a marine transgression after a brief emergence at the end of Oligocene. The middle Miocene is faunally and lithologically similar to the Marmarica Limestone of the western desert (Said, 1962b) and represents a continuity of similar chalky calcarenite deposition over several hundred miles along the southeastern coast of the Mediterranean.

The Gulf of Suez, like most of the rest of northeastern Africa, was emergent during the Oligocene and was again invaded by Teythian seas during the early Miocene. Miocene seas deposited in this embayment over 2900 meters of deep water marls and shales, which are called the Globigerina Marls. Most of this sequence is early Miocene in age, however, the upper part of the Globigerina Marls contrains Orbulina universa d'Orbigny and is considered middle Miocene in age. Following deposition of the Globigerina Marls, the flow of water into the Gulf of Suez became restricted, converting the gulf into a hypersaline basin (Barr, 1964, p. 138). A thick sequence of evaporites, consisting of alternating beds of anhydrite, shale, marl, and some dolomite, was deposited in this restricted basin. This sequence varies greatly in thickness throughout the Gulf of Suez area, in places attaining a thickness of several thousand meters. These sediments appear to conformably overlie the Globigerina Marls and in the past have usually been considered middle Miocene in age, although with little 
paleontologic evidence. Considering the new DSDP data on the middle and upper Miocene of the eastern Mediterranean, this age assignment should be reviewed.

\section{Upper Miocene (Messinian)}

It has long been recognized that the late Miocene was a time of regression in northern Africa, although the extent of this regression may not have been fully realized. There are, however, a number of reports of marine upper Miocene rocks in Libya and adjacent areas. It is the objective of this section to review some of these records.

In Tunisia, widespread emergence has often been recorded at the end of Miocene time (Burollet, 1956, 1967). Continental deposits of apparent upper Miocene age overlie Vindobonian sediments over a large portion of eastern Tunisia.

There have been several records of marine upper Miocene (Messinian) rocks in Libya. Berggren (1969) recorded several hundred feet of unconsolidated sands and sandy calcarenites overlying deep-water, open sea, Tortonian deposits in the northern Sirte Basin, which he tentatively assigned to the Messinian. These sediments contain a sparse microfauna consisting mainly of Elphidium, Ammonia, Asterigerina and Amphistegina. Although these forms occur in the late Miocene, they are not diagnostic of that age and could just as well be from the Pliocene or Pleistocene.

Another report of upper Miocene is recorded on the USGS geologic map of Libya (Conant and Goudarzi, 1964). It shows two main patches that are considered to be marine upper Miocene. The larger is an east-west band extending from Al Jaghbub to a point just north of Qasr as Sahabi. These sediments, which unconformably overlie the middle Miocene Al Jaghbub Formation, consist mainly of unconsolidated quartz sands with occasional beds of green shale and limestone. De Cesare, Franchino, and Sommaruga (1963) have made a detailed study of these beds and conclude that they are mainly continental deposits of Pliocene to Quaternary age. In a single sample, a few shallow marine foraminifera, including Ammonia, were recovered. It is uncertain if this represents a brief marine incursion, or alternatively, whether these foraminifers may have been derived from older beds. Nevertheless, these beds, which are given the name Garet Uedda Formation, are considered Pliocene or younger. It is probable that the sands considered by Berggren (1969) to be Messinian in the northern Sirte Basin are in part or wholly equivalent to the Garet Uedda Formation.

We have also had the opportunity to examine these same sediments which were penetrated by many shallow holes drilled north and east of Qasr as Sahabi. A few derived foraminifera were recovered from these sediments, but, as far as could be determined, the entire sequence, which consists predominantly of unconsolidated quartz sand, appeared to have had a continental origin.

In an early study of the Tertiary of Cyrenaica, Stefanini (1923) recorded the occurrence of upper Miocene (Pontian) rocks in several localities in northern Cyrenaica and Sirtica. These age assignments were made with considerable reservation, being based mainly on analogy with gypsiferous sulfur-bearing strata in Sicily. However, Desio (1935) disagreed with the late Miocene age attributed to these beds and was able to demonstrate that most of them were middle Miocene (Vindobonian) in age. Desio, however, thought upper Miocene strata did occur in a few restricted areas. He considered a sandy limestone found near Soluch and the limestone of Regima to be upper Miocene as they contained several fossils in common with a reported upper Miocene deposit found near the head of the Gulf of Suez. As no marine upper Miocene is now recognized in the Suez area, the age assignment for the Soluch limestone is questionable and a middle Miocene age has been demonstrated for the limestone at Regima (Kleinsmeide and van den Berg, 1968).

There have been several other reports of upper Miocene deposits in Libya, however, in each case there was no definitive paleontologic evidence for the determination. Although it remains impossible to disprove every report of possible marine Messinian sediments in Libya, evidence has yet to be presented that they do, in fact, occur. It is therefore suggested by the authors that it is quite probable that there are no marine Messinian sediments in Libya.

Marine Messinian strata do not appear to be present in the Western Desert of Egypt. Said (in Bellini, 1969, p. 181) states that marine carbonates of Pliocene age unconformably overlie the middle Miocene Marmarica Limestone. Mansour, Barkat, and Abdel Hady $(1969$, p. 839) record lower Pliocene sediments unconformably overlying the middle Miocene Marmarica Limestone along the Gulf of Salum in northwestern-most Egypt. Omara and Ouda (1969) also report Pliocene sediments unconformably overlying the middle Miocene in a well just west of Alexandria.

In the Cairo-Suez area, 20 meters of non-marine grits and gravels of probable upper Miocene age overlie the marine middle Miocene. These beds are unfossiliferous, but are similar to strata in the northern Gulf of Suez area where upper Miocene fresh-water snails have been reported (Said, 1962b).

\section{Pliocene}

After the major regression that brought the Miocene Epoch to a close, the Pliocene returned the Mediterranean Sea to some of the coastal areas of northeastern Africa (Figure 3).

During the Pliocene, most of Tunisia was emergent, with the sea occupying only a narrow band along the present eastern and northeastern coast. Cape Bon and the Bizerte Lake area received the greatest accumulation of sediments where fossiliferous clays and marls have an average thickness of over 300 meters.

There have been few reports of marine Pliocene strata in Libya. Desio (1935) recorded the occurrence of shallow marine sands and clays in the northern Sirte Basin which, although his paleontologic evidence was inconclusive, he considered Pliocene in age. On the geologic map of Libya (Conant and Goudarzi, 1964), three patches of marine and continental Pliocene deposits are shown (which include Desio's localities) located in an arc along the southeastern shore of the Gulf of Sirte (Figure 1).

Therefore, although the evidence is far from definitive, there is an indication that the Gulf of Sirte may have 
extended a short distance past its present shoreline during the Pliocene and covered an area south and east of $\mathrm{Al}$ Agheila and Agedabia. The rest of Libya was probably emergent.

Pliocene seas occupied the coastal area of the western Desert. In an important paper on this subject, Mansour, Barakat, and Abdel Hady (1969) record 78 meters of mainly sandy limestone that unconformably overlie the Marmarica Limestone along the southwestern shore of the Gulf of Salum and document its large foraminiferal fauna. They assign this sequence to two planktonic zones of the Lower Pliocene, the Sphaeroidinellopsis spp. Acme-zone and the Globorotalia margaritae Total-range-zone.

Further to the east, Omara and Ouda (1969) described a diverse foraminiferal fauna from 150 feet of soft clays and shales of Pliocene age that were penetrated by the Burg el Arab Well about $45 \mathrm{~km}$ west of Alexandria. This sequence rests unconformably on middle Miocene limestone.

In the subsurface of the Nile Delta, Viotti and Mansour (1969) recognized four planktonic zones which they considered belonging to the Miocene. They are: the Globigerina nilotica Zone, the Globigerina nepenthes Zone, the Sphaeroidinellopsis seminulina grimsdalei Zone, and the Globorotalia fohsi peripheroronda Zone. An unconformity is present separating the lowermost zone from the upper three units. The oldest zone, the Globorotalia fohsi peripheroronda Zone, is middle Miocene in age. However, in a re-evaluation of this work Mansour et al. (1969) now consider the upper three zones as lower Pliocene. The evidence therefore, indicates that an open sea planktonic facies of lower Pliocene age unconformably overlies an open sea facies of the middle Miocene with the upper Miocene being represented by a period of emergence.

\section{ORIGIN OF SAHABI CHANNEL}

In summary, there is a large-scale drainage system cut at least 1300 feet into middle Miocene limestone on the northeastern border of the Sirte Basin. The area of the drainage system is a flat low-lying region, much of which is less than 100 feet above sea level; some portions near the system's western extremity are at or a little below sea level. In general, this area does not appear to have been very much affected by Neogene tectonics.

There are two alternative hypotheses for the origin of the Sahabi channel system: one relies on the raising and lowering of the land area; the other utilizes a lowering and rising of the sea.

The first hypothesis invokes the following sequence of events. During post-middle Miocene times, a large portion of the Cyrenaican platform would have been raised epirogenically over 1300 feet above sea level (or above its present elevation). A large drainage system would rapidly develop, cutting sharply into the flat-lying middle Miocene limestone. This system would empty into the Mediterranean about at the apex of the present Gulf of Sirte. Following this brief period of emergence and erosion, the Cyrenaican platform would then be lowered the same amount that it had just been raised. Therefore, in a relatively short interval of time, the Cyrenaican platform would have been elevated at least 1300 feet, probably quite a bit more, and lowered the same amount. After the lowering, the drainage system would have been filled by fluvial and some eolian sediments.

The second, alternate hypothesis envisages great changes in the Mediterranean sea level. During post-middle Miocene time, there was a sudden drop in the sea level of the Mediterranean of at least 1300 feet, or probably considerably more since the Sahabi channel, where it is observed, would still have many miles to run before reaching the Mediterranean with a reduced sea level. The drainage would have been rapidly eroded into the middle Miocene limestone during this time of Mediterranean shrinkage. Then with equal rapidity, the sea level of the Mediterranean would rise returning to its former (and present) level. The drainage system, then below grade, would be filled with fluvial-eolian sediments.

Both hypotheses demand dramatic movements of land or sea. However, there are several lines of evidence that support the second hypothesis, which is favored by the authors:

(1) The area of this drainage system does not appear in other respects to have been tectonically active during the Neogene.

(2) A great lowering of the eastern Mediterranean sea level would produce other large scale, widespread drainage features. There have been several records of other, possibly related systems. Di Cesare, Franchino, and Sommaruga (1963, p. 38) describe a major fossil drainage pattern cut into the $\mathrm{Al}$ Jaghbub Formation located about $100 \mathrm{~km}$ southeast of the Sahabi channel, an area that presently receives very little rainfall. The drainage ran from northwest to southeast, although they state that it was sometimes reactivated in the opposite direction. These authors were able to date that drainage as post-middle Miocene to pre-Pleistocene. Bellini (1969, p. 167) also comments 'on this same ancient hydrographic system between Al Jaghbub and Gialo. Another ancient drainage system observed on aerial photographs has been recorded by Squyres and Bradley (1964, p. 101) in the Western Desert of Egypt. In addition, Chumakov (1967), using material from numerous bore holes, has documented a large channel in the Nile Valley of upper Egypt. This channel was cut into igneous bed rock by an ancestral Nile River 200 to 300 meters below the Nile's present level. The basal sediments filling this ancient channel consist of gray, montmorillonitic clays with thin lenses of fine-grained, micaceous sands and sandy loams that are rich in plant detritus. A uniform suite of authigenic minerals are present, including glauconite, zeolite, pyrite, and siderite. The sands are partially cemented by secondary calcite. Rare ostracods belonging to the genera Cypridea, Cyprinotus, Limnocythere, Eucypris, and Candoniella were recovered, which suggest a brackish environment of deposition and an early Pliocene age for the lower-most channel fill. Chumakov believes this channel to have been cut during late Miocene time, resulting in the formation of an enormous marine estuary in the Nile Valley during the early Pliocene.

(3) DSDP Leg 13 has added substantial support for the sea level lowering and rising hypothesis with the discovery of upper Miocene halite and other evaporites overlain by normal marine lower Pliocene sediments at various locations in the Mediterranean. Normal marine middle 
Miocene limestones and sandstones were also sampled in the eastern Mediterranean. Together, they suggest the same chronological sequence of environmental conditions that is indicated by the Neogene succession along the coastal area of northeastern Africa.

\section{Age of Sahabi Channel}

On the basis of direct paleontologic evidence, it can only be said that the cutting of the Sahabi channel took place during post-middle Miocene time. However, a regional review of the Miocene and Pliocene sediments of Libya and adjacent countries gives strong support to an upper Miocene age for this drainage system. Middle Miocene sediments were widespread across northeastern Africa. An abrupt regression then took place during the late Miocene, leaving Tunisia, Libya, and Egypt emergent and subject to subaerial erosion. This was followed by a lower Pliocene transgression which, however, only reached the coastal area of these countries.

This same sequence of events is recognized in the DSDP data in presently deep areas of the Mediterranean.

Further support for an upper Miocene age come from the observations of Di Cesare, Franchino and Sommaruga (1963, p. 38), who date the drainage system southeast of the Sahabi channel as upper Miocene or Pliocene. They demonstrate that it is post-Al Jaghbub Formation and pre-Garet Uedda Formation. As there is some evidence for a Pliocene age for some of the Garet Uedda Formation, this might suggest an upper Miocene age for this fossil drainage system.

\section{CONCLUSIONS}

The Sahabi channel which extends for about $150 \mathrm{~km}$ or more, is one of several late Tertiary drainage systems recognized in eastern Libya and western Egypt. This system has cut over 1300 feet below sea level into middle-Miocene rocks, probably during late Miocene time. It is suggested that a sudden drop in Mediterranean sea level of considerably more than 1300 feet was responsible for this deep drainage erosion. This was followed by a sudden rising of sea level during the early Pliocene back to a level perhaps a little lower than that just before the regression. This resulted in the Sahabi channel being below grade and therefore rapidly filled with fluvial and some eolian sediments.

The geomorphic observations in northeastern Africa suggest a series of widespread events that agree closely with those interpreted from data gained during drilling in the Mediterranean. It is suggested that the Gulf of Sirte might well provide a fruitful area for future oceanographic studies in relation to these observations in northern Libya. An investigation of the southeastern margin of the gulf to determine if evidence of a submerged drainage system is present and an examination of the east-central gulf for the possible occurrence of upper Miocene fans (possibly interdigitating with an evaporite sequence) would be of interest and might add important information to our knowledge of the Messinian paleogeography of the eastern Mediterranean area.

\section{ACKNOWLEDGMENTS}

The authors thank D. D. Skeels who examined the lithology in many of the shallow holes that penetrated the Sahabi channel system and Coy $\mathrm{H}$. Squyres who reviewed the manuscript and offered many valuable suggestions. Oasis Oil Company of Libya has granted permission to publish this paper.

\section{REFERENCES}

Barr, F. T., 1964. Geology of the Gulf of Suez Area. In Guidebook to the Geology and Archaeology of Egypt. F. A. Reilly (Ed.). Petrol. Explor. Soc. Libya. 123. Tripoli.

Bellini, E., 1969. Biostratigraphy of the "Al Jaghbub (Giarabub) Formation" in Eastern Cyrenaica (Libya). Proc. 3rd African Micropal. Colloquium. 165, pl. 1. Cairo.

Berggren, W. A., 1969. Biostratigraphy and Planktonic Foraminiferal Zonation of the Tertiary System of the Sirte Basin of Libya, North Africa. Proc. 1st Internat. Conf. on Planktonic Microfossil. 104. Geneva.

Burollet, P. F., 1956. Contribution a l'étude stratigraphique de la Tunisie Centrale. Ann. des Mines et de la Geol. 18 , 350 p. pls. 1-22. Tunis.

1967. Tertiary Geology of Tunisia. In Guidebook to the Geology and History of Tunisia. L. Martin (Ed.). Petrol. Explor. Soc. Libya. 215. Tripoli.

Chumakov, I. S., 1967. Pliocene and Pleistocene deposits of the Nile Valley in Nubia and Upper Egypt (in Russian). Acad. Science U.S.S.R. Geol. Institute, Trans. 170, p. 5. Moscow.

Conant, L. C. and Goudarzi, G. H., 1964. Geologic Map of Kingdom of Libya. U. S. Geol. Survey, Misc. Geol. Inv., Map I-350A.

Desio, A., 1935. Missione scientifica della Reala Accademia d'Italia a Cufra (1931-IX); vol. I, Studi geologici sulla Cirenaica, sul Deserto Libico, sulla Tripolitania e sul Fezzan Orientali. Reale Accad. d'Italia, Viaggi di Studio ed Esploranzioni. 1, pls. 1-6, map, Rome.

Di Cesare, F., Franchino, A. and Sommaruga, C., 1963. The Pliocene-Quaternary of Giarabub Erg Region. Proc. First Sharan Symposium. Rev. de l'Institut Francais du Petrole. $18(10,11), 30$.

Kleinsmeide, W. F. J. and van den Berg, N. J., 1968. Surface Geology of the Jabal al Akhdar, Northern Cyrenaica, Libya. In Geology and Archaeology of Northern Cyrenaica, Libya. F. T. Barr (Ed.). Petrol. Explor. Soc. Libya. 115, 2 pls., geol. map, Tripoli.

Mansour, A. T., Barakat, M. G. and Abedel Hady, Y. el S., 1969. Marine Pliocene Planktonic Foraminiferal Zonation South-east of Salum, Egypt. Riv. Ital. Paleont. 75 (4), 833. pls. 59-61.

Omara, S. and Ouda, K., 1969. Pliocene Foraminifera from the sub-surface rocks of Burg el Arab Well No. 1, Western Desert, Egypt. Proc. 3rd African Micropal. Colloquium. 581,5 pls., Cairo.

Said, R., 1962a. Das Miozän in der westlichen Wüste Ägyptens. Geol. Jb. 80, 349, pls. 30, 31 .

1962b. The Geology of Egypt. (Elsevier Publ. Co.). 377 pp., 10 pls., 17 tables, Amsterdam, New York.

Squyres, C. H. and Bradley, W. B., 1964. Notes on the Western Desert of Egypt. In Guidebook to the Geology and Archaeology of Egypt. F. A. Reilly (Ed.). Petrol. Explor. Soc. Libya. 99, pl. 1, Tripoli.

Stefanini, G., 1923. Fossili terziari della Cirenaica. Paleontogr. Italica. 27, 101. Pisa. 
Viotti, C. and Mansour, A., 1969. Tertiary Planktonic Foraminiferal Zonation from the Nile Delta, Egypt, U.A.R., Part I: Miocene Planktonic Foraminiferal Zona- tion. Proc. 3rd African Micropal. Colloquium. 425, pls. 1-5. Cairo.

\title{
44.5. THE EUSTATIC HYPOTHESIS AND THE PRE-PLIOCENE CUTTING OF THE RHONE VALLEY
}

\author{
Georges Clauson, Laboratoire de G'eographie Physique, Universite d'Aix-Marseille, 13, Aix-en-Provence, France
}

The finding of an extensive layer of evaporites in the deep drillings in the Mediterranean revives a new interest in the hypothesis of a temporary isolation of this sea at the end of the Miocene. Since this idea has already received support from the interpretation of boreholes within the Rhone Valley in southern France, I have been invited to first trace the history of this hypothesis, and then examine how it provides a unique solution to a number of problems of continental paleogeography.

\section{BACKGROUND AND HISTORY OF THE "DENIZOT HYPOTHESIS"}

The eustatic hypothesis is far from being a new idea. Ever since Depéret (1895), it has been entertained by a number of authors. However, they always relied on a worldwise cause for sea-level change without ever really commenting on its origin.

It was Denizot who first offered an explanation for the extraordinary amplitude of the regression which was believed to have occurred in the Mediterranean basin. In a paper published in 1952 on the Pliocene in the Rhone
Valley, he explicitly developed the concept of an isolation of the Mediterranean. Consequently, I refer to it here as the "Denizot hypothesis." The original text is worth quoting: ${ }^{1}$

"Il y eut une régression de la fin du Miocène, d'une très grande généralité, qu'on reconnait aussi sur le versant atlantique: c'est un tel system de vallées que la mer pliocène devait envahir, à l'embouchure actuelle de la Loire. Mais en outre, pour ce qui est de la Méditerranée à ce moment, les détroits espagnols et marocains s'étant fermés, et avant que ne s'ouvre celui de Gibraltar, il s'est produit un séparation complète de cette mer. Elle s'est alors réduite à une lagune, et a évolué indépendamment suivant les conditions climatiques: il y eut baisse de son niveau, en se bordant d'une frange littorale où peuvent singulièrement voisiner étangs saumâtres et lagunes de concentration. Telle est maintenant, en moins grand, la Mer Caspienne.

A la phase suivante s'ouvre le détroit de Gibraltar: la Méditerranée reprend le caractère de mer normale et transgresse sur ses côtes en même temps que fait l'Altantique. Cette mer envahit alors le réseau fluvial qui venait de se creuser et notamment la vallée du Rhône, objet de la

\footnotetext{
${ }^{1}$ Editor's translation-

"There was a regression of the sea at the end of the Miocene over a widespread area which was observed also on the Atlantic coast: it is such a system of valleys that the Pliocene sea had to invade to the mouth of the Loire itself. With the connecting passageways across Spain and Morocco closed and the Gibraltar Strait not yet opened, the Mediterranean at that moment became completely isolated. It was subsequently reduced to a lagoon and evolved independently according to climatic influence: there was a drop in sea level such that the bordering coastal fringe became
}

occupied by brackish ponds and saline lagoons. On a smaller scale, the Caspian Sea is such an example.

In the following period the Strait of Gibraltar opened: the Mediterranean took back its normal character and the sea transgressed its coasts at the same time as did the Atlantic. This sea invaded the fluvial network previously incised, in particular the valley of the Rhône which is the object of present study. Other authors have often commented on the various aspects of the Pliocene transgression: its widespread occurrence evoking a raising of the entire surface of the sea-that is an eustatic movement." 